\title{
Riwayat Berat Badan Lahir dengan Kejadian Stunting pada Anak Usia Bawah Dua Tahun
}

\author{
Birth Weight Records with Stunting Incidence among Children under Two \\ Years Old
}

\author{
Atikah Rahayu*, Fahrini Yulidasari**, Andini Octaviana Putri**, Fauzie Rahman**
}

\begin{abstract}
*Bagian Gizi Program Studi Kesehatan Masyarakat, Fakultas Kedokteran, Universitas Lambung Mangkurat, Banjarmasin, Indonesia, **Bagian KIA dan Administrasi Kebijakan Kesehatan Program Studi Kesehatan Masyarakat, Fakultas Kedokteran, Universitas Lambung Mangkurat, Banjarmasin, Indonesia
\end{abstract}

DOI: http://dx.doi.org/10.21109/kesmas.v10i2.882

\begin{abstract}
Abstrak
Kabupaten Hulu Sungai Utara masih dihadapkan dengan permasalahan gizi pada anak bawah dua tahun (baduta). Salah satu masalah gizi hingga saat ini adalah stunting. Anak dengan riwayat berat badan lahir rendah (BBLR) merupakan salah satu faktor yang potensial memengaruhi pertumbuhan anak. Penelitian ini bertujuan untuk mengkaji risiko riwayat berat badan lahir dengan kejadian stunting pada anak baduta. Desain penelitian adalah potong lintang. Populasi penelitian ini merupakan ibu-ibu yang memiliki anak baduta dan besar sampel sejumlah 117 terdiri dari anak baduta. Pelaksanaan penelitian dilakukan selama tiga bulan pada bulan September - November 2014. Kategori BBLR jika riwayat berat badan lahir $<2.500$ gram. Analisis data bivariat menggunakan uji kai kuadrat dan data multivariat menggunakan uji regresi logistik. Hasil analisis bivariat menunjukkan bahwa terdapat hubungan yang signifikan antara riwayat status BBLR (nilai $p=0,015$ ) dengan stunting pada anak baduta. Berdasarkan hasil analisis multivariat, diperoleh bahwa BBLR merupakan faktor risiko yang paling dominan berhubungan dengan kejadian stunting. Anak dengan BBLR memiliki risiko 5,87 kali untuk mengalami stunting. Riwayat BBLR memiliki peranan penting dalam kejadian stunting anak baduta di wilayah Puskesmas Sungai Karias, Hulu Sungai Utara.

Kata Kunci: Berat badan lahir rendah, status pekerjaan ibu, stunting, tinggi badan ayah, tinggi badan ibu
\end{abstract}

\section{Abstract}

North Hulu Sungai District is still facing nutrition problems among children under two years old. One of nutrition problems up to now is stunting. Child with low birthweight (LBW) record is one of potential factors influencing the growth of a child. This study aimed to assess any risk of LBW records with stunting incidence among children under two years old. This study used cross-sectional design. The population was mothers having children under two years old and samples amounted to 117 consisted of children under two years old. This study was conducted within three months on September November 2014. Category of LBW was if birth weight records $<2,500$ gram. Bivariate data analysis used chi-square test and multivariate data analysis used logistic regression test. The result of bivariate analysis showed a significant relation between LBW status records ( $p$ value $=0.015$ ) with stunting incidence among children under two years old. Based on the result of multivariate analysis, LBW was the most dominating risk factor related to stunting incidence. Children with LBW had 5.87 times risk of suffering from stunting. LBW records take an important role in stunting incidence among children under two years old around Sungai Karias Primary Health Care area in North Hulu Sungai.

Keywords: Low birthweight, mother's occupation status, stunting, father's body height, mother's body height

\section{Pendahuluan}

Salah satu indikator terbaik untuk melihat status gizi anak bawah lima tahun (balita) adalah pertumbuhan. Pertumbuhan pada masa ini penting karena merupakan salah satu indikator kesehatan di masa dewasa. ${ }^{1}$ Pada tahun 2015, program perbaikan gizi telah menargetkan masalah gizi, baik gizi lebih maupun gizi kurang hanya mencapai $15,5 \% .^{2}$ Di Indonesia, malnutrisi yang terjadi pada anak bawah dua tahun (baduta) merupakan masalah pokok kesehatan masyarakat yang harus segera diatasi karena dapat mengganggu pertumbuhan. ${ }^{3}$

Korespondensi: Atikah Rahayu, Bagian Gizi Prodi Kesmas FK Lambung Mangkurat, Jl. A. Yani KM 36 Banjarbaru, Banjarmasin, Kalimantan Selatan 70714, No. Telp: 0511-4772747,e-mail:nindya.fitria@gmail.com 
Gangguan pertumbuhan terjadi pada usia balita, khususnya baduta dapat meningkatkan risiko penyakit kronis pada usia dewasa. ${ }^{1}$ Salah satu gangguan pertumbuhan pada masa tersebut adalah stunting. Hasil Riset Kesehatan Dasar (Riskesdas) di Indonesia dan penelitian di Vietnam, menemukan bahwa kejadian stunting meningkat pada usia satu hingga dua tahun. ${ }^{3,4}$

Data Riskesdas 2007 di Provinsi Kalimantan Selatan menunjukkan prevalensi stunting baduta mencapai 35,3\% dan pada tahun 2013 mencapai 45\%. Data ini menunjukkan bahwa prevalensi stunting mengalami peningkatan. Besarnya prevalensi stunting ini telah masuk dalam kategori masalah kesehatan masyarakat yang sangat buruk. 4,5 Puskesmas Sungai Karias yang berada di wilayah kerja Amuntai Tengah memiliki delapan desa yang sebagian besar berada di pinggiran sungai dan digunakan masyarakat untuk budi daya ikan. Berdasarkan hasil Riskesdas yang dilakukan di Amuntai Tengah pada tahun 2013, anak baduta yang mengalami stunting sebesar $51 \% .6$ Penyebab utama stunting di antaranya adalah hambatan pertumbuhan dalam kandungan, asupan zat gizi yang tidak mencukupi untuk mendukung pertumbuhan dan perkembangan yang cepat pada masa bayi dan anakanak serta seringnya terkena penyakit infeksi selama masa awal kehidupan. ${ }^{4}$ Selain itu, berdasarkan hasil penelitian Kusumawati et al, ${ }^{7}$ faktor yang memengaruhi stunting antara lain sebagian besar karena anak mengalami penyakit infeksi, anak memiliki panjang badan yang rendah ketika lahir, pemberian makanan tambahan yang tidak sesuai menurut usia disertai dengan konsistensi makanannya dan anak yang mengalami berat lahir yang rendah pada saat dilahirkan. Selain itu, menurut Arifeen et al, ${ }^{8}$ status gizi ibu sebelum dan ketika hamil juga turut berperan mencetuskan kejadian berat badan lahir rendah (BBLR).

Masa baduta disebut sebagai 'masa kritis'. Salah satu indikator masa kritis adalah ketika anak lahir dengan BBLR. Prevalensi BBLR nasional sebesar $11,1 \%$, namun prevalensi ini lebih rendah dibandingkan prevalensi BBLR Provinsi Kalimantan Selatan sebesar 16,6 \%.6 Besarnya prevalensi BBLR dapat disebabkan oleh bebe-rapa faktor risiko. Hasil penelitan Ernawati et al, ${ }^{9}$ menemukan 9,5\% bayi dengan berat badan lahir rendah dan $22 \%$ di antaranya mengalami stunting. Menurut Soekirman dan United Nations Children's Emergency Fund (UNICEF), 10 status gizi rendah secara langsung dapat dipengaruhi oleh asupan zat gizi yang rendah maupun keganasan penyakit infeksi. Jika tidak ditanggulangi, kondisi ini akan berlanjut hingga anak tumbuh menjadi remaja. ${ }^{10}$ Berdasarkan permasalahan tersebut, maka diperlukan kajian tentang hubungan antara riwayat berat badan lahir dengan kejadian stunting pada anak usia baduta.

\section{Metode}

Pengumpulan data menggunakan desain penelitian potong lintang dengan rancangan analitik. Penelitian ini dilaksanakan di daerah bantaran sungai wilayah Puskesmas Sungai Karias, Kabupaten Hulu Sungai Utara selama tiga bulan pada tahun 2014. Pemilihan wilayah puskesmas berdasarkan purposive karena besarnya kejadian stunting di wilayah tersebut. Populasi adalah ibu-ibu yang memiliki baduta di daerah bantaran sungai wilayah Puskesmas Sungai Karias, Kabupaten Hulu Sungai Utara. Sampel pada penelitian ini adalah ibu yang memiliki anak usia baduta. Kriteria inklusi sampel adalah ibu bersedia menandatangani informed consent, anak sehat, dan tidak memiliki cacat bawaan. Adapun teknik pengambilan sampel adalah dari jumlah anak pada periode window of opportunity 0 - 2 tahun terdaftar sebanyak 164 orang, kemudian besar sampel dihitung menggunakan rumus Slovin dengan hasil sebanyak 117 sampel. Mengacu pada kriteria inklusi sampel yang telah ditentukan, sampel dipilih secara random pada tiga posyandu yang tersebar di wilayah Puskesmas Karias. Posyandu A sejumlah 63 sampel, Posyandu B berjumlah 21 sampel, dan Posyandu C berjumlah 33 sampel. Data yang dikumpulkan antara lain status pekerjaan ibu, tinggi badan ayah dan ibu, riwayat status BBLR, dan kejadian stunting. Anak dikategorikan sangat pendek bila panjang badan menurut usia ( $\mathrm{z}$-skor $<-3,0 \mathrm{SD}$ ), pendek bila panjang badan menurut usia $(\geq-3 \mathrm{SD}$ s.d $<-2$ SD) dan tidak/normal bila panjang badan menurut usia $(\geq-2 \mathrm{SD})$ berdasarkan baku rujukan World Health Organization (WHO) antropometri 2006. Pekerjaan ibu merupakan kependudukan atau posisi seseorang dalam kelompok masyarakat yang dapat dilihat dari aktivitasnya seharihari dan menghasilkan pendapatan yang dikategorikan menjadi bekerja dan tidak bekerja. Orangtua yang bekerja, selain aktif dan menghasilkan pendapatan, mereka dapat bekerja sebagai pegawai negeri sipil, wiraswasta, petani, nelayan, buruh, layanan jasa maupun pekerjaan lainnya yang dapat menghasilkan uang. Tinggi badan ayah dan ibu merupakan panjang skeletal tubuh orangtua berdasarkan pengukuran tinggi badan menurut usia. Menurut Hizni et al, ${ }^{11}$ bahwa tinggi badan ayah dapat dikategorikan menjadi $<-2$ SD $(<160$ centimeter $)$ dan $\geq$ -2SD ( $\geq 160$ centimeter), dan menurut hasil Riskesdas bahwa tinggi badan ibu dapat dikategorikan menjadi <2 SD ( 150 centimeter) dan $\geq-2$ SD ( $\geq 150$ centimeter) pada ibu.

Kategori BBLR jika riwayat berat badan lahir $<2.500$ gram, dan tidak BBLR jika riwayat berat badan lahir $\geq$ 2.500 gram. Instrumen yang digunakan untuk mengetahui data ibu seperti status pekerjaan ibu, tinggi badan ayah dan ibu, riwayat status BBLR, dan kejadian stunting menggunakan formulir isian responden dan sampel. Pengumpulan data panjang badan baduta diukur oleh tenaga terlatih menggunakan baby length board. Usia dan jenis kelamin anak diketahui dari wawancara. 
Analisis data melalui tiga tahap, yaitu analisis univariat untuk mendeskripsikan data menggunakan tabel distribusi frekuensi dan persentase, analisis bivariat dengan uji kai kuadrat pada tingkat kemaknaan 95\% dengan confidence interval (CI) 95\%, dipergunakan untuk mengkaji hubungan antara status pekerjaan ibu, tinggi badan ayah dan ibu, riwayat status BBLR, dan kejadian stunting pada baduta dan analisis multivariat menggunakan uji regresi logistik untuk mengetahui variabel yang paling dominan berhubungan dengan kejadian stunting pada anak usia baduta di wilayah Puskesmas Sungai Karias, Kabupaten Hulu Sungai Utara.

\section{Hasil}

Tabel 1 menunjukkan bahwa karakteristik responden sebagian besar tidak bekerja sebanyak 79 responden $(67,5 \%)$. Tinggi badan ayah maupun ibu kategori tinggi jumlahnya lebih besar, dimana tinggi badan ayah kategori $\geq 160$ centimeter sejumlah 111 responden $(94,9 \%)$, dan kategori tinggi badan $\geq 150$ centimeter sebesar 98 responden (ibu) $(83,8 \%)$. Hasil penelitian ini juga telah menemukan bahwa masih terdapat responden yang melahirkan anak yang mengalami riwayat berat bayi lahir rendah, yaitu sebesar 11 responden $(9,40 \%)$. Bayi yang lahir dengan berat rendah dari normal berpotensi menghambat tinggi badan ketika usianya semakin bertambah. Terhambatnya tinggi badan ini disebut dengan stunting. Hasil penelitian menunjukkan bahwa masih ditemukan responden yang memiliki anak dengan stunting sebesar

Tabel 1. Distribusi Karakteristik Keluarga

\begin{tabular}{llll}
\hline Variabel & Kategori & $\mathbf{n}$ & $\%$ \\
\hline Status pekerjaan ibu & Bekerja & 38 & 32,5 \\
& Tidak bekerja & 79 & 67,5 \\
Tinggi badan ayah & $<160$ centimeter & 6 & 5,1 \\
& $\geq 160$ centimeter & 111 & 94,9 \\
Tinggi badan ibu & $\geq 150$ centimeter & 98 & 83,8 \\
Riwayat status BBLR & $<150$ centimeter & 19 & 16,2 \\
& BBLR & 11 & 9,40 \\
Status stunting & Tidak BBLR & 106 & 90,6 \\
& Stunting & 55 & 47,0 \\
& Tidak stunting & 62 & 53,0 \\
\hline
\end{tabular}

55 responden $(47 \%)$.

Tabel 2 menunjukkan bahwa sebagian besar anak yang mengalami stunting memiliki ibu tidak bekerja sebesar 38 orang $(32,5 \%)$. Berdasarkan hasil uji statistik, diperoleh nilai $\mathrm{p}=0,873$ yang menunjukkan bahwa walaupun ibu memiliki waktu luang yang relatif banyak, namun tidak memiliki efek positif bagi perawatan dan pengasuhan yang baik dalam menjaga pertumbuhan anaknya. Selain itu, diketahui bahwa sebagian besar anak yang stunting memiliki ayah dan ibu dengan tinggi badan kategori $\geq-2$ SD masing-masing sebesar 52 orang $(44,4 \%)$ dan 43 orang $(36,8 \%)$. Berdasarkan hasil uji statistik, diperoleh nilai $\mathrm{p}$ adalah 0,880 (tinggi badan ayah) dan nilai $\mathrm{p}$ adalah 0,123 (tinggi badan ibu) yang menunjukkan bahwa stunting yang dialami anak baduta di Puskesmas Sungai Karias, Hulu Sungai Utara berpotensi disebabkan karena faktor lain seperti anak tidak mendapatkan air susu ibu (ASI) secara eksklusif, pemberian makanan pendamping ASI (MPASI) yang tidak tepat menurut usia anak dan konsistensi makanan yang diberikan serta status gizi ibu hamil yang masih rendah, selain tinggi badan baik ibu maupun ayah. Hasil penelitian ini menemukan bahwa stunting yang dialami anak usia baduta disebabkan karena anak tersebut memiliki berat lahir yang rendah ketika lahir $(<2.500$ gram). Berdasarkan hasil analisis statistik, diperoleh nilai $\mathrm{p}$ adalah 0,015 dengan nilai OR hasil analisis ini 5,87 yang berarti bahwa anak dengan berat yang rendah ketika lahir berpeluang 5,87 kali lebih berisiko mengalami stunting dibanding anak tidak BBLR.

Berdasarkan Tabel 2, diketahui bahwa variabel bebas riwayat status BBLR dan tinggi badan ibu memiliki nilai signifikansi yang telah memenuhi syarat dilakukannya analisis lanjutan menggunakan perhitungan uji regresi logistik. Variabel ini dievaluasi, kemudian dilakukan uji interaksi. Uji ini dilakukan pada variabel yang diduga secara substansi terdapat interaksi. Tabel 3 berikut ini merupakan hasil akhir model multivariat menggunakan uji regresi logistik.

Berdasarkan Tabel 3, diketahui bahwa riwayat BBLR

Tabel 2. Hubungan Karakteristik Keluarga dengan Status Gizi Anak

\begin{tabular}{|c|c|c|c|c|c|c|c|}
\hline \multirow{3}{*}{ Variabel } & \multirow{3}{*}{ Kategori } & \multicolumn{4}{|c|}{ Status gizi } & \multirow{3}{*}{$\begin{array}{l}\text { OR } \\
95 \% \mathrm{CI}\end{array}$} & \multirow{3}{*}{ Nilai $p$} \\
\hline & & \multicolumn{2}{|c|}{ Stunting } & \multicolumn{2}{|c|}{ Tidak Stunting } & & \\
\hline & & $\mathbf{n}$ & $\%$ & $\mathbf{n}$ & $\%$ & & \\
\hline \multirow{2}{*}{ Status pekerjaan ibu } & Bekerja & 17 & $(14,5 \%)$ & 21 & $(17,9 \%)$ & 0,785 & \multirow{2}{*}{0,873} \\
\hline & Tidak bekerja & 38 & $(32,5 \%)$ & 41 & $(35,1 \%)$ & $(0,36-1,71)$ & \\
\hline \multirow[t]{2}{*}{ Tinggi badan ayah } & $<-2 \mathrm{SD}(\leq 160 \mathrm{~cm})$ & 3 & $(2,6 \%)$ & 3 & $(2,6 \%)$ & 1,135 & \multirow[t]{2}{*}{0,880} \\
\hline & $\geq-2 \mathrm{SD}(>160 \mathrm{~cm})$ & 52 & $(44,4 \%)$ & 59 & $(50,4 \%)$ & $(0,23-6,09)$ & \\
\hline \multirow[t]{2}{*}{ Tinggi badan ibu } & $<-2 \mathrm{SD}(\leq 150 \mathrm{~cm})$ & 12 & $(10,2 \%)$ & 7 & $(5,9 \%)$ & 2,193 & \multirow[t]{2}{*}{0,123} \\
\hline & $\geq-2 \mathrm{SD}(>150 \mathrm{~cm})$ & 43 & $(36,8 \%)$ & 55 & $(47,1 \%)$ & $(0,83-6,30)$ & \\
\hline \multirow[t]{2}{*}{ Riwayat status BBLR } & BBLR & 9 & $(7,7 \%)$ & 2 & $(1,71 \%)$ & 5,870 & \multirow[t]{2}{*}{$0,015^{*}$} \\
\hline & Tidak BBLR & 46 & $(39,3 \%)$ & 60 & $(51,3 \%)$ & $(1,26-29,61)$ & \\
\hline
\end{tabular}


Tabel 3. Hasil Uji Regresi Logistik Variabel Riwayat Status BBLR dan Tinggi Badan Ibu terhadap Kejadian Stunting

\begin{tabular}{lcccc}
\hline Variabel Bebas & B & Nilai p & OR & 95\% CI \\
\hline Riwayat BBLR & 1,862 & 0,022 & 1,555 & $0,032-0,762$ \\
Tinggi badan ibu & 0,892 & 0,090 & 0,410 & $0,146-1,149$ \\
\hline
\end{tabular}

memiliki nilai signifikan 0,022 dan tinggi badan ibu memiliki nilai $\mathrm{p}=0,090$. Pada Tabel 3 diketahui bahwa riwayat BBLR merupakan variabel yang memiliki keeratan hubungan paling besar terhadap stunting pada anak baduta. Hal ini didasarkan pada hasil analisis multivariat yang menunjukkan bahwa riwayat BBLR dengan nilai p paling mendekati nilai alpha $(\alpha)<0,05$. Nilai OR hasil dari analisis ini menunjukkan bahwa nilai OR riwayat BBLR adalah 1,555 artinya anak baduta yang memiliki riwayat BBLR berisiko stunting 1,555 kali dibandingkan dengan baduta yang tidak mengalami BBLR. Sedangkan tinggi badan ibu merupakan confounding sehingga harus dikontrol.

\section{Pembahasan}

Pekerjaan merupakan salah satu faktor yang memengaruhi sosial ekonomi sebuah keluarga. Ibu yang bekerja tentunya dapat menambah pendapatan bagi keluarga, nantinya juga turut berperan dalam menentukan status ekonomi keluarga. Dengan berperannya ibu dalam menambah pendapatan keluarga, maka kesempatan ibu untuk mengasuh dan merawat anak semakin sedikit sehingga akan memengaruhi status gizi anak. Hal ini sesuai dengan hasil penelitian Hizni et al, 11 bahwa anak yang mengalami stunting disebabkan memiliki ibu yang bekerja purna waktu. Begitu pula hasil penelitian Arma, ${ }^{12}$ menemukan sebesar $80 \%$ ibu yang bekerja memiliki anak yang tidak normal pertumbuhan dan perkembangannya. Kondisi ini terjadi karena ibu bekerja, memiliki keterbatasan waktu untuk merawat anaknya. Berbeda dengan hasil penelitian ini, bahwa walaupun ibu bekerja, namun anak yang mengalami stunting jumlahnya lebih sedikit yaitu 17 orang $(14,5 \%)$ dibandingkan anak yang tidak stunting sejumlah 21 orang $(17,9 \%)$. Anak yang memiliki ayah dan ibu yang bekerja cenderung memiliki status ekonomi yang lebih baik. Dengan status ekonomi keluarga yang baik, maka akan memengaruhi kemampuan pemenuhan gizi keluarga maupun kemampuan mendapatkan layanan kesehatan. Orangtua dengan sosial ekonomi yang baik cenderung memiliki pendidikan yang tinggi. Dengan pendidikan yang tinggi lebih mudah dan cepat memperoleh akses media informasi serta mudah untuk menyerap informasi kesehatan yang baik bagi pertumbuhan dan perkembangan anak. Sebaliknya, anak pada keluarga dengan tingkat ekonomi rendah lebih berisiko mengalami stunting kare- na selain terbatasnya untuk memperoleh akses layanan kesehatan, keluarga juga memiliki kemampuan pemenuhan gizi yang rendah sehingga meningkatkan risiko terjadinya gizi salah. Selain itu, status ekonomi yang rendah berhubungan dengan keterbatasan keluarga dalam memenuhi kebutuhan akan zat gizi baik makro maupun mikro. Status ekonomi keluarga yang rendah akan memengaruhi kualitas maupun kuantitas bahan makanan yang dikonsumsi oleh keluarga. Makanan yang didapat biasanya akan kurang bervariasi dan sedikit jumlahnya terutama pada bahan pangan yang berfungsi untuk pertumbuhan anak seperti sumber protein, vitamin dan mineral sehingga meningkatkan risiko kurang gizi pada anak. ${ }^{7}$ Selain itu, kondisi rendahnya kualitas dan kuantitas makanan yang dikonsumsi ibu hamil berpotensi juga memengaruhi produksi ASI. Akibat dari produksi ASI yang tidak lancar bahkan kurang, maka anak tidak mendapat cukup asupan zat gizi yang penting untuk pertumbuhan dan perkembangannya melalui ASI, akibatnya berisiko mengalami gizi kurang maupun gangguan pertumbuhan dan perkembangan. Senada dengan hasil penelitian Fatmah dan Nurasiah, ${ }^{13}$ bahwa keluarga yang memiliki sosial ekonomi yang mapan cenderung lebih mengonsumsi makanan ringan yang mengandung tinggi energi dibandingkan kelompok keluarga yang memiliki sosial ekonomi rendah yang hanya memilih konsumsi makanan ringan berkalori rendah.

Hasil penelitian ini menunjukkan bahwa anak yang mengalami stunting tidak berhubungan dengan tinggi badan ayah maupun ibu. Pada Tabel 2 terlihat bahwa anak yang mengalami stunting lebih besar memiliki ayah dan ibu dengan tinggi badan kategori tidak pendek sebesar 52 orang $(44,4 \%)$ dan 43 orang $(36,8 \%)$. Kondisi sesuai menurut UNICEF bahwa tinggi badan orangtua bukan merupakan penyebab langsung yang memengaruhi status gizi anak, namun faktor penyebab secara langsung kurang gizi adalah ketidakcukupan makanan yang dikonsumsi dan penyakit infeksi yang mungkin dialami oleh anak. Selain itu, kemampuan orangtua dalam menyediakan makanan tingkat rumah tangga yang kurang, kurang baiknya cara orangtua dalam merawat anak, lingkungan keluarga yang tidak terjaga kebersihannya serta kemampuan keluarga dalam memanfaatkan layanan kesehatan terbatas merupakan pokok masalah gizi kurang pada anak. ${ }^{14}$ Berbeda dengan hasil penelitian Dangour, ${ }^{15}$ di Kazakhastan membuktikan bahwa ibu yang pendek akan melahirkan anak yang pendek pula. Hasil penelitian tersebut dilakukan pada anak berusia 6 - 59 bulan. Selain itu, menurut Hanum, ${ }^{16}$ ibu yang memiliki tinggi badan pendek $(<150$ centimeter) akan meningkatkan kejadian stunting pada anak. Baik pada penelitian Dangour, ${ }^{15}$ maupun Hanum, ${ }^{16}$ menunjukkan bahwa stunting pada anak disebabkan faktor alami yang diturunkan oleh ibunya kepada anaknya melalui genotif 
pendek yang terdapat pada diri ibu. Senada dengan dua penelitian sebelumnya menurut Nasikhah, ${ }^{17}$ menunjukkan bahwa anak yang mengalami stunting terlahir dari ibu yang memiliki tinggi badan pendek. Penelitian ini tidak meneliti faktor-faktor yang memengaruhi tinggi badan ayah maupun ibu sehingga tidak dapat dibedakan tinggi badan ayah maupun ibu dipengaruhi oleh faktor genetik maupun malnutrisi.

Hasil penelitian ini menemukan bahwa kondisi stunting yang dialami anak tidak disebabkan oleh tinggi badan ayah maupun ibunya. Hasil ini sejalan dengan penelitian yang dilakukan oleh Yustiana, ${ }^{18}$ bahwa tidak terdapat hubungan antara tinggi badan ayah (nilai $\mathrm{p}=$ 0,082 ) dan tinggi badan ibu (nilai $\mathrm{p}=0,935$ ) dengan status stunting pada anak. Hasil penelitian di Kota Semarang dengan sampel penelitian balita usia satu sampai dua tahun juga menunjukkan hasil yang sama, yaitu tinggi badan ibu bukan merupakan faktor risiko kejadian stunting. ${ }^{19}$ Jika ibu dan ayah tergolong pendek, anak berpotensi memiliki risiko memiliki tubuh yang pendek pula karena anak mewarisi gen dalam kromosom yang membawa sifat stunting. Akan tetapi, tinggi badan dipengaruhi oleh pelbagai faktor, tidak hanya faktor genetik saja (tinggi badan orangtua), tetapi juga dipengaruhi asupan nutrisi dan juga penyakit yang diderita. Jika anak mengalami stunting karena kurangnya asupan gizi sejak kecil, maka stunting pada keturunannya masih dapat ditanggulangi. ${ }^{18}$ Tidak adanya hubungan antara tinggi badan ibu dengan stunting pada anak dalam penelitian ini kemungkinan dapat disebabkan karena jumlah sampel yang diteliti sedikit.

Tabel 2 menunjukkan bahwa anak yang mengalami stunting berhubungan dengan riwayat BBLR (nilai $\mathrm{p}=$ 0,015). Anak yang memiliki riwayat BBLR berpeluang 5,87 kali lebih tinggi untuk mengalami stunting. Menurut hasil penelitian di Kota Banda Aceh, anak yang dilahirkan dengan BBLR berisiko mengalami stunting. ${ }^{20}$ Senada dengan hasil penelitian Rahmad et al, ${ }^{20}$ penelitian Mardani et al,21 telah menemukan bahwa faktor prediksi yang berpengaruh terhadap stunting pada balita adalah BBLR. Anak yang terlahir dengan BBLR lebih berpotensi stunting dibandingkan anak yang terlahir dengan berat normal. ${ }^{22-24}$ Selain itu, menurut Lin et al, ${ }^{25}$ berat badan bayi lahir rendah (BBLR $<2.500$ gram) telah diidentifikasi sebagai faktor risiko penting terkait perkembangan anak selanjutnya. Menurut penelitian Abenhaim, ${ }^{26}$ bayi yang disebut lahir rendah adalah bila berat bayi lahir dengan berat kurang dari 2.500 gram dan empat kali lebih tinggi mengakibatkan kematian jika dibandingkan dengan berat bayi terlahir $2.500-3.000$ gram.

Berat lahir pada umumnya sangat terkait dengan kematian janin, neonatal dan pascaneonatal, morbiditas bayi dan anak serta pertumbuhan dan perkembangan jangka panjang. Dampak dari bayi yang memiliki berat lahir rendah akan berlangsung dari generasi ke generasi, anak dengan BBLR akan memiliki ukuran antropometri yang kurang pada perkembangannya. Dalam analisis multivariat tunggal variabel berat lahir rendah memiliki dampak yang besar terhadap stunting. Hasil penelitian yang dilakukan oleh Mugni et al, ${ }^{27}$ menunjukkan bahwa berat lahir merupakan prediktor yang signifikan dalam menentukan status pendek pada bayi usia $12-60$ bulan di Makassar. Hasil penelitian ini sejalan pula dengan beberapa penelitian sebelumnya yang menemukan bahwa terdapat hubungan yang signifikan antara riwayat status BBLR dengan status stunting pada baduta. Menurut Arifin et al,28 anak dengan BBLR yang diiringi dengan konsumsi makanan yang tidak adekuat, pelayanan kesehatan yang tidak layak, dan sering terjadi infeksi pada masa pertumbuhan akan terus mengakibatkan terhambatnya pertumbuhan dan menghasilkan anak yang stunting. Hasil penelitian Siza, ${ }^{29}$ dan Jaya, ${ }^{30}$ menemukan bahwa salah satu faktor eksternal yang berhubungan dengan berat bayi lahir rendah adalah status pekerjaan ibu.

Senada dengan hasil penelitian Siza, ${ }^{29}$ dan Jaya, ${ }^{30}$ penelitian ini menemukan bahwa sebagian besar anak stunting memiliki ibu tidak bekerja sebesar 38 orang $(32,5 \%)$. Status pekerjaan erat kaitannya dengan aktivitas menghasilkan pendapatan. Menurut hasil penelitian di Mexico, apabila orangtua tidak bekerja, khususnya ibu yang dapat membantu menambah penghasilan keluarga, maka memengaruhi keluarga dalam mengakses pelayanan kesehatan yang memadai. Selain itu, dengan penghasilan yang rendah, ibu tidak mampu untuk melindungi dan menjaga keseimbangan berat badan ketika hamil. ${ }^{31}$ Hasil penelitian Djaali dan Eryando, 32 menemukan bahwa anak yang terlahir dengan berat badan yang rendah memiliki ibu dengan tingkat pendidikan yang rendah pula. Berbeda dengan hasil penelitian yang dilakukan oleh Nurcahyani dan Trihandini, ${ }^{33}$ anak yang dilahirkan dengan berat lahir yang rendah disebabkan karena ibunya masih belum berkeinginan untuk hamil sebelumnya.

Berdasarkan hasil analisis regresi logistik, diperoleh bahwa anak dengan riwayat BBLR akan memiliki tubuh pendek. Nilai OR riwayat status BBLR adalah 0,155 artinya anak baduta yang memiliki riwayat BBLR 0,155 kali lebih besar berisiko mengalami stunting dibandingkan dengan baduta yang tidak mengalami BBLR atau baduta yang tidak mengalami BBLR sebagai protektor terhadap kejadian stunting. Menurut penelitian Suwarni et al, ${ }^{34}$ bayi dengan BBLR antara lain dapat mengalami hambatan pertumbuhan atau stunting. Sebagian besar bayi dengan kondisi BBLR kemudian diiringi dengan stunting terdapat pada bayi berjenis kelamin perempuan. Oleh karena itu, kondisi ini perlu ditanggulangi sejak dini mengingat berat bayi lahir rendah merupakan masalah 
kesehatan masyarakat yang banyak terjadi di negara-negara miskin dan berkembang yang erat kaitannya dengan mortalitas dan morbiditas bagi janin, anak maupun generasi penerus. ${ }^{35}$ Selain itu, untuk mencegah kurang gizi sangat berarti untuk kelompok usia dua tahun pertama karena kerentanan anak terhadap penyakit dan resiko kematian masih tetap tinggi di usia tersebut. Itulah sebabnya banyak intervensi kesehatan dan gizi yang difokuskan pada dua tahun pertama kehidupannya. 36 Sedangkan hasil penelitian Fikawati et al, ${ }^{37}$ bayi lahir dengan berat badan tidak mencapai standar normal disebabkan karena ibunya ketika sebelum hamil memiliki pola makan yang tidak mengonsumsi makanan bersumber protein hewani. Penelitian ini tidak meneliti faktor-faktor yang memengaruhi BBLR sehingga tidak dapat dibedakan status BBLR dipengaruhi oleh riwayat pola makan ibu yang berpantang mengonsumsi protein bersumber hewani atau faktor lain.

\section{Kesimpulan}

Faktor risiko yang paling dominan berhubungan dengan anak yang mengalami stunting adalah BBLR. Sedangkan variabel status pekerjaan ibu, tinggi badan ayah dan tinggi badan ibu tidak berhubungan dengan kejadian stunting pada anak baduta di bantaran sungai wilayah Puskesmas Sungai Karias, Kabupaten Hulu Sungai Utara.

\section{Saran}

Penelitian lebih lanjut diperlukan untuk mengkaji pola asuh orangtua terhadap anak yang mengalami stunting akibat BBLR, pengetahuan gizi ibu dalam menyediakan makanan bagi anak stunting, asupan gizi disertai dengan pemberian makanan menurut periode usia anak. Selain itu, mengingat kondisi stunting merupakan cerminan dari riwayat gizi masa lalu maka penting pula mengkaji secara retrospektif peran aktif ibu hamil dalam memantau perkembangan kesehatan saat hamil, asupan gizi ibu ketika hamil dan pengetahuan gizi ibu mengenai makanan yang harus dikonsumsi selama hamil.

\section{Ucapan Terima Kasih}

Peneliti mengucapkan terima kasih kepada Direktorat Pendidikan Tinggi melalui Fakultas Kedokteran Universitas Lambung Mangkurat yang telah mendanai penelitian ini dan responden yang telah bersedia untuk dijadikan subjek dalam penelitian, Kepala Dinas Kesehatan Kabupaten Hulu Sungai Utara, Kepala Puskesmas Sungai Karias, ahli gizi wilayah Puskesmas Sungai Karias serta semua pihak yang telah turut berpartisipasi terlaksananya penelitian ini.

\section{Daftar Pustaka}

1. Victoria CG, Adair L, Fall C, Hallal PC, Martorell R, Ritcher L, et al.
Maternal and child undernutrition: consequences for adult health and human capital. Lancet. 2008; 371: 340-57.

2. Citrakesumasari. Analisis situasi ibu dan baduta global, nasional, Sulawesi Barat dan Kabupaten Polman [manucsript on internet]. Makassar: Universitas Hasanuddin; 2012 [cited 2014 Dec 5]. Avalaible from: http://repository.unhas.ac.id/bitstream/handle/123456789/4530/ ANALISIS\%20SITUASI\%20IBU\%20DAN\%20ANAK.pdf

3. Badan Penelitian dan Pengembangan Kesehatan Republik Indonesia. Riset kesehatan dasar 2010. Jakarta: Kementerian Kesehatan Republik Indonesia; 2010.

4. Vaktskjold A, Van Tri D, Trong Phi D, Sandanger T. Stunted growth in a cohort of two-years old in The Khanh Hoa Province in Vietnam: a follow up study. Journal of Rural and Tropical Public Health. 2010; 9: 7781.

5. Badan Penelitian dan Pengembangan Kesehatan Republik Indonesia. Riset kesehatan dasar tahun 2007. Jakarta: Departemen Kesehatan Republik Indonesia; 2007.

6. Badan Penelitian dan Pengembangan Kesehatan Republik Indonesia. Riset kesehatan dasar 2013. Jakarta: Kementerian Kesehatan Republik Indonesia; 2013.

7. Kusumawati E, Rahardjo S, Sari HP. Model pengendalian faktor risiko stunting pada anak bawah tiga tahun. Kesmas: Jurnal Kesehatan Masyarakat Nasional. 2015; 9 (3)

8. Arifeen SE, Black RE, Caulfield LE, Antelman G, Baqui AH, Nahar Q, et al. Infant growth patterns in the slum Dhaka in reletion to birth weight intrauterine growth retardation and prematurity. American Journal Clinical Nutrition. 2004; 72 (4): 1010-7.

9. Ernawati F, Muljati S, Dewi MS, Safitri A. Hubungan panjang badan lahir terhadap perkembangan anak usia 12 bulan. Jurnal Penelitian Gizi dan Makanan. 2014; 37 (2): 109-118

10. Soekirman. Ilmu gizi dan aplikasinya untuk keluarga dan masyarakat. Jakarta: Direktorat Jenderal Pendidikan Tinggi, Departemen Pendidikan Nasional Republik Indonesia; 2000.

11. Hizni A, Julia M, Gamayanti IL. Status stunted dan hubungannya dengan perkembangan anak balita di Wilayah Pesisir Pantai Utara Kecamatan Lemahwungkuk Kota Cirebon. Jurnal Gizi Klinik Indonesia. 2010; 6 (3): 131-7.

12. Arma AJA. Faktor-faktor yang mempengaruhi tumbuh kembang bayi ibu bekerja (Nakerwan) di Sentra Industry. Jurnal Nusantara. 2001; 34 (3): $139-45$

13. Fatmah, Nurasiah. Kebiasaan makan ibu dan anak usia 3-5 tahun pada kelompok sosio-ekonomi tinggi dan rendah di Kelurahan Rambutan dan Penggilingan Jakarta Timur. Jurnal Makara Kesehatan. 2002; 6: 17-24

14. UNICEF. The state of the world's children 1998. Oxford: Oxford University Press; 1998

15. Dangour AD, Hill HL, Ismail SJ. Height, weight, and haemoglobin status of 6 to 59 month old Kazah children living in Kzyl-Oeda Region, Kazakhtan. Europe Journal Clinical Nutrition. 2002; 56: 1030-8.

16. Hanum F, Khomsan A, Heryatno Y. Hubungan asupan zat gizi dengan tinggi badan ibu dengan status gizi anak balita. Jurnal Gizi dan Pangan. 2014; 9:1-6.

17. Nasikhah R. Faktor risiko kejadian stunting pada baduta usia 24-36 bulan di Kecamatan Semarang Timur [manuscript on internet]. Semarang: Universitas Diponegoro; 2012 [cited 2014 Dec 10]. Available from: 
https://core.ac.uk/download/files/379/11736670.pdf

18. Yustiana K. Perbedaan panjang badan bayi baru lahir antara ibu hamil KEK dan tidak KEK [undergraduate thesis]. Semarang: Universitas Diponegoro; 2013.

19. Candra A, Puruhita N, Susanto JC. Risk factors of stunting among 1-2 years old children in Semarang City. Media Medika Indonesian. 2011; 45 (3): 206-12.

20. Rahmad AH, Miko A, Hadi A. Kajian stunting pada anak balita ditinjau dari pemberian ASI eksklusif, MP-ASI, status imunisasi dan karakteristik keluarga di Kota Banda Aceh. Jurnal Kesehatan Ilmiah Nasuwakes. 2013; 6 (2): 169-84

21. Mardani RAD, Wetasin K, Suwanwaiphatthana W. Faktor prediksi yang mempengaruhi terjadinya stunting pada anak usia dibawah lima tahun. Jurnal Kesehatan Masyarakat. 2015; 11 (1): 1-7.

22. Ajao KO, Ojefitimi EO, Adebayo AA, Fatusi AO, Afolali OT. Influence of family size, household food security status, and child care practices on the nutritional status of under-five children in Ile-Ife, Nigeria. African Journal of Reproductive Health. 2010; 14 (4): 123-32.

23. Rayhan MI, Khan M. Factors causing malnutrition among under five children in Bangladesh. Pakistan Journal of Nutrition. 2006; 5 (6): 5585562

24. Cophra M. Risk factors for undernutrition of young children in rural area of South Africa. Public Health Nutrition. 2003; 6 (7): 645.

25. Lin CM, Chen CW, Chen PT, Lu TH, Li CY. Risks and causes of mortality among low birthweight infants in childhood and adolescence. Paediatric and Perinatal Epidemiology. 2007; 21: 465-72.

26. Abenhaim HA, Kinch RA and Usher R. Effect of prepregnancy body mass indexcategories on obstetric and neonatal outcomes. Obstetric and Gynaecologic. 2004; 2004; 103: 219-24.

27. Muqni AD, Hadju V, Jafar N. Hubungan berat badan lahir dan pelayanan KIA terhadap status gizi anak balita di Kelurahan Tamamaung Makassar. Media Gizi Masyarakat Indonesia. 2012; 1 (2): 109-16.
28. Arifin DZ, Irdasari SY \& Sukandar H. Analisis sebaran dan faktor risiko stunting pada baduta di Kabupaten Purwakarta 2012 [manuscript on internet]. Bandung: Universitas Padjajaran; 2012 [cited 2015 Jan 4]. Available from: http://pustaka.unpad.ac.id/wp-content/uploads/2013/07/pustaka_unpad_analisis_sebaran_dan_faktor_risiko_stu nting.pdf

29. Siza JE. Risk factors associated wit low birth weight of neonates among pregnant women attending a referral hospital in Northern Tanzania. Tanzania Journal of Health Research. 2008; 10: 1-8.

30. Jaya N. Analisis faktor risiko kejadian berat bayi lahir rendah di Rumah Sakit Ibu dan Anak Siti Fatimah Kota Makassar. Media Gizi Pangan. 2009; 7: 49-54.

31. Leroy JF, Habicht JP, de Cossio TG, and Ruel MT. Maternal education mitigates the negative effects of higher income on the double burden of child stunting and maternal overweight in rural Meksiko. The Journal of Nutrition. 2014; 5: 765-70.

32. Djaali NA, Eryando T. Bayi berat lahir rendah di Rumah Sakit Umum Daerah Pasar Rebo dan faktor-faktor yang berhubungan. Kesmas: Jurnal Kesehatan Masyarakat Nasional. 2010; 5 (2): 71-5.

33. Nurcahyani DA, Trihandini I. Kehamilan yang tidak diinginkan dan berat badan lahir bayi. Kesmas: Jurnal Kesehatan Masyarakat Nasional. 2013; 7 (8): 354-9.

34. Suwarni Y, Syahadatina M, Rahayu A. Hubungan antara paritas, LILA, kadar $\mathrm{Hb}$, dan usia ibu hamil dengan berat lahir bayi. Jurnal Publikasi Kesehatan Masyarakat Indonesia. 2015; 1(1): 60-6.

35. Simbolon D. Model prediksi indeks massa tubuh remaja berdasarkan riwayat lahir dan status gizi anak. Kesmas: Jurnal Kesehatan Masyarakat Nasional. 2013; 8 (1): 19-27.

36. Huriah T, Trisnantoro L, Haryanti F, Julia M. Upaya peningkatan status gizi balita malnutrisi akut berat melalui program home care. Kesmas: Jurnal Kesehatan Masyarakat Nasional. 2014; 9 (2): 130-6.

37. Fikawati S, Wahyuni D, Syafiq A. Status gizi ibu hamil dan berat lahir bayi pada kelompok vegetarian. Makara Kesehatan. 2012; 16 (1): 29-35. 